\title{
Oxygen budgets in subtidal arctic (Kongsfjorden, Svalbard) and temperate (Helgoland, North Sea) microphytobenthic communities
}

\author{
D. S. Sevilgen ${ }^{1,2,4, *}$, D. de Beer ${ }^{2}$, A. Y. Al-Handal ${ }^{3}$, T. Brey ${ }^{1}$, L. Polerecky ${ }^{2,5}$ \\ ${ }^{1}$ Alfred-Wegener-Institut, PO Box 120161, 27515 Bremerhaven, Germany \\ ${ }^{2}$ Max Planck Institute for Marine Microbiology, Celsiusstraße 1, 28359 Bremen, Germany \\ ${ }^{3}$ Marine Science Centre, Dept. of Marine Biology, University of Basra, Iraq \\ ${ }^{4}$ Present address: Alfred-Wegener-Institut, Helmholtz Centre for Polar and Marine Research, Am Alten Hafen 26, \\ 27568 Bremerhaven, Germany \\ ${ }^{5}$ Present address: Faculty of Geosciences, Utrecht University, Budapestlaan 4, 3584 CD, Utrecht, The Netherlands
}

\begin{abstract}
We compared primary production and respiration of temperate (Helgoland, North Sea) and subtidal Arctic (Kongsfjorden, Svalbard) microphytobenthic communities during summer. The diatom communities were generally characterized as cosmopolitan, displayed no site specificity, and had similar chl $a$ and fucoxanthin concentrations. Their net and gross photosynthesis rates and light adaptation intensities, derived from laboratory microsensor measurements, were also similar, despite differences in water temperature. Daily oxygen fluxes across the sediment-water interface were estimated by combining laboratory microprofile and planar optode measurements with in situ data on oxygen penetration and light dynamics. During the study period, the Svalbard sediments were on average net heterotrophic, while the Helgoland sediments were net autotrophic $\left(-22.4\right.$ vs. $\left.9.2 \mathrm{mmol} \mathrm{O}_{2} \mathrm{~m}^{-2} \mathrm{~d}^{-1}\right)$. This was due to high infaunal abundance in the Svalbard sediments that caused high oxygen uptake rates in the sediments and consumption below the sediment euphotic zone. Additionally, bioirrigation of the sediment due to infaunal burrow ventilation was reduced by light; thus, the sedimentary oxygen inventory was reduced with increasing light. Conversely, light-enhanced the oxygen inventory in the Helgoland sediments. Oxygen dynamics in the Svalbard sediments were therefore dominated by bioirrigation, whereas in the Helgoland sediments they were dominated by photosynthetic oxygen production.
\end{abstract}

KEY WORDS: Benthic primary production - Sandy sediments - Microsensors - Planar optodes · Photosynthesis $\cdot$ Respiration $\cdot P$-I curve $\cdot$ Bioirrigation

\section{INTRODUCTION}

The microphytobenthos (MPB) is comprised of communities of photosynthetic microorganisms (diatoms, dinoflagellates and cyanobacteria) that live in the uppermost surface layers of the seafloor (MacIntyre et al. 1996). It constitutes a food source for heterotrophic organisms and can significantly affect solute exchange across the sediment-water interface. The MPB in sandy and muddy habitats is dominated mostly by diatoms (Sundbäck et al.
1991, MacIntyre et al. 1996). In coastal areas, MPB production can be similar to or exceed phytoplankton production, and thus the MPB contributes significantly to ecosystem primary production (MacIntyre et al. 1996, Cahoon 1999, 2006, Underwood \& Kromkamp 1999, Glud et al. 2002). On average, benthic microalgae productivity in shallow waters $(<30 \mathrm{~m})$ in the Artic exceeds pelagic productivity (by 50\%; Glud et al. 2009).

Studies on MPB communities range from temperate to tropical regions, and across various habitats, 
such as brackish lagoons, salt marshes, intertidal flats and subtidal sediments (MacIntyre et al. 1996, Cahoon 1999, 2006, Underwood \& Kromkamp 1999, Glud et al. 2009). MPB organisms are the major primary producers in intertidal flats (Scholz \& Liebezeit 2012) and are accordingly well-studied for that habitat (e.g. MacIntyre et al. 1996, Denis et al. 2012, Scholz \& Liebezeit 2012). However, studies on subtidal MPB communities are lacking, notably from the German North Sea area, although a few studies have examined MPB and benthic food webs in other parts of the North Sea (Riaux-Gobin et al. 1987, Reiss et al. 2007, Evrard et al. 2010).

Glud et al. (2009) noted that the subtidal MPB, particularly in colder waters and high latitudinal regions like the Arctic, is grossly under-sampled. This is a significant knowledge gap, given that the Arctic continental shelf area accounts for $\sim 1 / 4$ of the global shelf area (areas with less than $200 \mathrm{~m}$ water depth; Menard \& Smith 1966, Jakobsson 2002), of which 1/5 receives enough light to support MPB organisms (Gattuso et al. 2006). It is likely that these systems are sensitive and will respond rapidly to global change effects such as ocean warming. The drastic decline of sea ice cover in the Arctic (Serreze et al. 2007, Zhang et al. 2012, Laxon et al. 2013) will change underwater light regimes, with more light becoming available earlier in the year and for longer time periods. As the MPB can quickly adapt to ambient light conditions (Kühl et al. 2001, Glud et al. 2002), these changes could stimulate pelagic and benthic primary production. Increasing temperature will additionally stimulate benthic productivity and remineralization. For example, Hancke \& Glud (2004) examined the response of photosynthesis and respiration in benthic communities to short-term elevated temperature in 1 high Arctic and 2 temperate MPB communities. Their results showed that both processes were stimulated, respiration more so than photosynthesis. The response of the MPB was similar at all sites, indicating no latitudinally related temperature adaptation. Similarly, Wieland \& Kühl (2000) examined oxygen and sulfide cycling in hypersaline microbial mats from Solar Lake, Egypt, and found that a short-term temperature increase stimulated respiration more than photosynthesis. Thus, it appears that at elevated temperatures benthic systems will gradually become more heterotrophic, and that this trend will hold across large geographical distances.

In this study, we aimed to contribute to the body of available literature that compares the activity of MPB communities from geographical regions characterized by largely different prevailing temperatures. Of particular interest were subtidal communities, to redress the under-sampling referred to above. As study sites, we chose subtidal sediments from the Arctic (Kongsfjorden, Svalbard) and from a temperate site in the North Sea (Helgoland). Despite the north-south distance of about $2800 \mathrm{~km}\left(25^{\circ}\right.$ latitude) between the 2 sites, they are oceanographically closely connected by the same North Atlantic water masses. The West Spitsbergen Current transports warm waters of the North Atlantic Current along the western coast of Svalbard, influencing the fjord systems along the coastline (Svendsen et al. 2002, Hop et al. 2012).

Specifically, our aim was to describe and compare habitat characteristics, MPB communities, primary production and oxygen dynamics at the 2 sites. We hypothesized that (1) oxygen dynamics in the sediments are controlled by MPB activity, and that (2) the 2 sites show differences in temperature, light and MPB community composition, but that the photosynthetic performance of the MPB communities is similar as a result of optimal adaptation to local conditions. We conducted laboratory experiments using oxygen microsensors to determine net photosynthesis and respiration rates as a function of light, and planar optodes to measure deeper sediment respiration. Additionally, we monitored in situ oxygen distributions in the sediments and incident light intensities over a period of at least $24 \mathrm{~h}$ and combined these data with the laboratory results to estimate daily oxygen budgets.

\section{MATERIALS AND METHODS}

\section{Study areas and sampling}

This study was carried out in shallow subtidal sediments from Svalbard (Arctic, Norway, 7856' N $11^{\circ} 51^{\prime} \mathrm{E}$ ) and Helgoland (North Sea, Germany, $\left.54^{\circ} 10^{\prime} \mathrm{N} 7^{\circ} 54^{\prime} \mathrm{E}\right)$. The Svalbard site, called Brandal, is located in the glacial fjord Kongsfjorden (Fig. 1A). The fjord, located at the western coast of Svalbard, is influenced by water masses of the West Spitsbergen Current, coastal arctic water and, in the inner part, by 4 large tidal glaciers terminating at the east and north sides of the fjord (Svendsen et al. 2002). The estimated annual average water temperature is slightly above $0^{\circ} \mathrm{C}$, and the diurnal tidal range is approximately 2 m (Ito \& Kudoh 1997, Hop et al. 2002, Svendsen et al. 2002). The Helgoland site, Düne Süd, is located about $100 \mathrm{~m}$ south-west from the Helgoländer Düne, which is an island located in the south- 

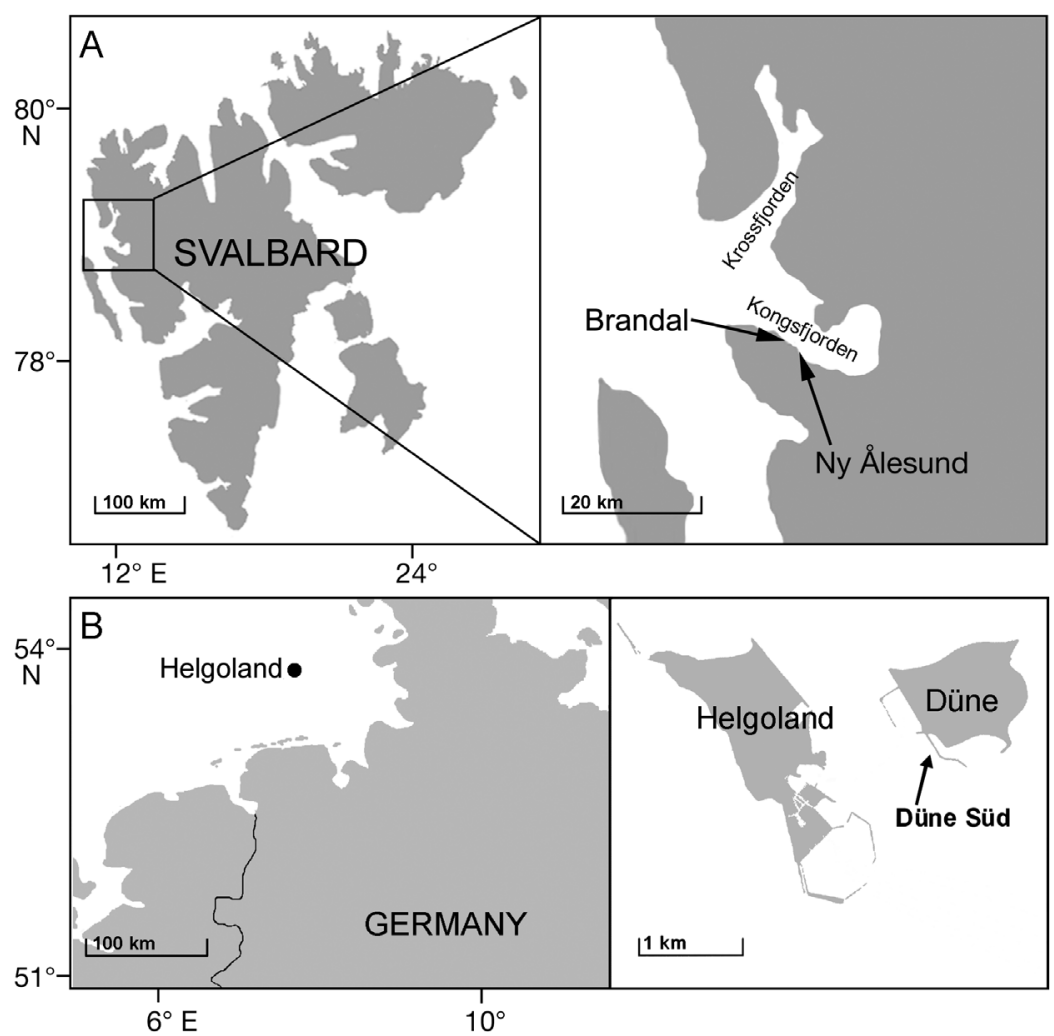

Fig. 1. Locations of the 2 study sites (A) Brandal (Svalbard, Arctic, Norway) and (B) Düne Süd (Helgoland, North Sea, Germany). Modified from https:// maps.google.com

eastern part of the North Sea (Fig. 1B). Average annual water temperature is around $10^{\circ} \mathrm{C}$, and the tidal range is about $2 \mathrm{~m}$ (Wiltshire et al. 2008).

Sampling and measurements were carried out at water depths of about $5 \mathrm{~m}$ through the summer months of 2009-2012. They included sediment characterization, in situ measurements of oxygen and light, sampling for porewater nutrients and MPB biomass, and laboratory measurements of photosynthesis and respiration in freshly collected sediment samples (Table 1).

\section{Sediment characterization}

Sediments were collected by scuba divers using cylindrical acrylic cores (inner diameter: $50 \mathrm{~mm}$, length: $200 \mathrm{~mm}$ ). The cores were sliced into $2 \mathrm{~cm} \mathrm{sec-}$ tions and each section was desalinated and dried at $80^{\circ} \mathrm{C}$ until constant weight. The grain size distribution, sorting and skewness were determined as described in Wentworth (1922) and Friedman \& Sanders (1978), using a sieve-column with mesh sizes of $63,125,250,500,1000$ and $2000 \mu \mathrm{m}$. Porosity was determined from weight loss on drying. Sediment permeability was measured in 2 cores per site with a constant head permeameter (Klute \& Dirksen 1986).

\section{Biogeochemical characterization of sediments and porewaters}

Total carbon (TC), nitrogen and sulfur contents in freeze-dried and ground samples of the sediment (depth intervals $0-1,1-2,2-4,4-6,6-8$, 8-10 cm) were determined by high temperature combustion (Carlo Erba NA-1500 CNS analyzer). Total inorganic carbon (TIC) was measured in a $\mathrm{CO}_{2}$ Coulometer (CM 5012, UIC) after acidification with $20 \%$ (w/v) phosphoric acid (CM 5130 Acidification module UIC). Total organic carbon was calculated as TOC $=$ TC - TIC.

Porewater for the analysis of nutrients $\left(\mathrm{NO}_{2}^{-}, \mathrm{NO}_{3}{ }^{2-}, \mathrm{NH}_{4}{ }^{+}, \mathrm{PO}_{4}{ }^{2-}, \mathrm{Si}^{2+}\right)$ was sampled in situ by scuba divers using soil moisture samplers $(10 \mathrm{~cm}$ Rhizon samplers, pore size $0.1 \mu \mathrm{m})$. For vertical profiles, a bottomless plastic bucket ( $30 \mathrm{~cm}$ diameter) was pushed 20 to $25 \mathrm{~cm}$ into the sediment, emptied and left to rest for between 24 and $72 \mathrm{~h}$. Subsequently, rhizones were inserted horizontally from the inside of the bucket outwards into the sediment through holes made at $2 \mathrm{~cm}$ vertical intervals down to a maximum depth of $12 \mathrm{~cm}$. Porewater was extracted either with a syringe or into vacuum vials. Samples were immediately transported to the laboratory and analyzed for nutrients using a 5 channel QuAAtro nutrient analyzer (Seal) equipped

Table 1. Overview of the measurement and sampling activities conducted at the Arctic ('Brandal', Kongsfjorden, Svalbard, Norway) and temperate ('Düne Süd', Helgoland, North Sea) study sites. nd: not determined

\begin{tabular}{|c|c|c|}
\hline Activity & Svalbard & Helgoland \\
\hline $\begin{array}{l}\text { Oxygen profiles/ } \\
\text { incident light (in situ) }\end{array}$ & Jun 2010 & Aug 2009 \\
\hline Sediment & Jun 2010 & Aug 2009 \\
\hline Porewater nutrients & Jun 2010 & nd \\
\hline $\begin{array}{l}\text { Photosynthesis and respi- } \\
\text { ration rates (laboratory) }\end{array}$ & Jun-Jul 2011 & Jun-Aug 2009 \\
\hline MPB pigments & Jun 2012 & May 2012 \\
\hline
\end{tabular}


with a Jasco fluorometer for $\mathrm{NH}_{4}{ }^{+}$analyses. $\mathrm{NH}_{4}{ }^{+}$ was analyzed as described in Kerouel \& Aminot (1997), and specific analytical protocols for the remaining nutrients were applied (Seal Analytical).

\section{Photopigment analyses}

Concentrations of chl $a$ and fucoxanthin were used as a measure of MPB biomass. The upper $3 \mathrm{~mm}$ of the sediment in the sampled sediment cores (area $19.6 \mathrm{~cm}^{2}$ ) were freeze-dried and weighed. To extract the pigments, $1.5 \mathrm{ml} 99.8 \%$ acetone was added, the samples were vortexed for $5 \mathrm{~s}$, left in an ultrasound bath with iced water for $3 \mathrm{~min}$, and then stored at $-28^{\circ} \mathrm{C}$ for $24 \mathrm{~h}$ in the dark. The extracts were filtered (Acro disc CR $4 \mathrm{~mm}$ syringe filters with a $0.45 \mu \mathrm{m}$ PTFE membrane) and analyzed by high performance liquid chromatography (HPLC) as described in Wright et al. (1991). The HPLC system consisted of a Waters 2695 separation module and a Waters 996 photodiode array detector (Waters, MA). Pigment standards supplied by DHI, Denmark, were used for calibration. The MPB samples were originally taken from the same cores where photosynthesis and respiration rates were measured by microsensors (see 'Materials and methods: Ex situ oxygen microprofile measurements' below). However, because these samples were lost, pigments were analyzed from a later measurement campaign (Table 1).

\section{Diatom identification}

Sub-samples of the upper $5 \mathrm{~mm}$ of sediment cores ( 2 per site) were taken and fixed in Lugol's solution for the identification and quantification of diatoms. Diatom samples were first washed with deionized water to remove salts, and then cleaned by boiling in $30 \%$ hydrogen peroxide. A few drops of $50 \%$ hydrochloric acid were added to the diatom suspension to ensure the removal of the hydrogen peroxide, which was followed by several rinses with distilled water. Cleaned diatoms were allowed to settle on cover slips, which were placed on a metal tray that was kept stable, protected from any disturbance. After air-drying at room temperature, permanent diatom slides were made using Naphrax diatom mountant medium. Diatoms were identified and photographed using a Zeiss Axioplan 2 light microscope (Carl Zeiss $\mathrm{AB})$ with differential interference contrast. Relative occurrence of species was estimated on 3 levels: (1) very rare (observed only once per slide), (2) rare (a few specimens per slide) and (3) frequent (at least 1 value in each microscope field and up to $10 \%$ of all values in a slide). Diatom taxonomic identification was mainly based on Hustedt (1958, 1961-1966), Hendey (1964), Germain (1981), Krammer \& LangeBertalot (1986, 1988, 2000), Witkowski et al. (2000) and Scott \& Thomas (2005).

\section{In situ light and temperature measurements}

In situ intensities of downwelling photosynthetically active radiation (PAR) were measured in 30 or $60 \mathrm{~s}$ intervals using submersible light-loggers (Odyssey Dataflow Systems) positioned at the sediment surface close to the points were the microsensor measurements were done. In situ temperature at the Svalbard site was measured at $5 \mathrm{~m}$ depth in $20 \mathrm{~min}$ intervals over 1 year (June 2011-June 2012) using HOBO Pendant and TidbiT loggers (ONSET). Because similar measurements could not be done at Helgoland, temperature data for this site were taken from the Helgoland Roads data series (Wiltshire et al. 2008).

\section{In situ oxygen microprofile measurements}

Vertical oxygen microprofiles in the sediment were measured in situ with amperometric Clark-type oxygen microelectrodes (Revsbech 1989) connected to a diver-operated microsensor profiler (Weber et al. 2007). Sensors had a tip diameter of 10 to $50 \mu \mathrm{m}$ and a stirring sensitivity of $<1.5 \%$. Linear calibration of the sensors was derived from in situ measurements in the anoxic parts of the sediment and from laboratory measurements in air-bubbled seawater at in situ temperature. Subsequently, in situ $\mathrm{O}_{2}$ concentrations were calculated based on the measured salinity and temperature (Li \& Gregory 1974, Garcia \& Gordon 1992). Profiles were continuously measured during at least $24 \mathrm{~h}$, with 2 replicate time-series in Svalbard and one in Helgoland. Measurements were done on sand plains with a visible cover of diatoms, as identified by the light red-brown color of the sediment surface. A semi-circular steel grid (10 cm height) was set up $\sim 15 \mathrm{~cm}$ in front of the sensor to prevent possible entanglement with floating macroalgae.

\section{Ex situ oxygen microprofile measurements}

Laboratory microsensor measurements were carried out in the Marine Laboratory at Ny Ålesund, 
Svalbard, and at the Biologische Anstalt Helgoland. Sediment samples were randomly collected in close vicinity to the in situ microsensor measurements and transported to a climate room, where they were stored for a maximum of $48 \mathrm{~h}$ in a flow-through system with natural seawater. During storage, temperature and light conditions mimicked those determined in situ, the latter achieved by a programmable illumination system (GHL Profilux PLUS II). The Helgoland samples were illuminated with a stepless light:dark cycle of 15:9 h with a maximum light intensity of $100 \mu \mathrm{mol}$ photons $\mathrm{m}^{-2} \mathrm{~s}^{-1}$ (higher maximum light intensities could not be reached due to set-up limitations). In contrast, continuous illumination was applied to the Svalbard samples, with intensities varying between 30 and $130 \mu \mathrm{mol}$ photons $\mathrm{m}^{-2} \mathrm{~s}^{-1}$ over a $24 \mathrm{~h}$ period.

Vertical profiles of oxygen were measured in 3 replicate sediment cores for each site. During the measurements, the samples were kept at in situ temperature using a thermostat (Julabo F32) or by using water that was continuously pumped from a water tank in the climate room. Illumination was provided by a halogen lamp (Schott KL 1500), and the measurements were made at downwelling light intensities increasing from 0 to $600 \mu \mathrm{mol}$ photons $\mathrm{m}^{-2} \mathrm{~s}^{-1}$. At each intensity level, oxygen profiles were measured at 3 to 5 randomly selected positions in the core after a delay of 30 to $60 \mathrm{~min}$ to ensure steady state. The Svalbard sediments contained large numbers of bioirrigating infauna, which disturbed the microsensor measurements. To minimize this disturbance, the overlaying water was made anoxic (by purging with $\mathrm{N}_{2}$ ) before the measurement, which temporarily stopped bioirrigating activity. Alternatively, the upper $5 \mathrm{~mm}$ of the sediment were removed, and the rest of the sediment was sieved to remove the larger animals. After reestablishing the sediment layers, the core was let to rest for $12 \mathrm{~h}$ in the climate room at in situ light and temperature conditions before the measurement. This treatment was not required for the Helgoland samples.

\section{Photosynthesis and respiration rate calculations}

Areal rates of net photosynthesis, $P_{\text {net }}$ and respiration, $R_{\text {phot }}$ in the euphotic layer of the sediment were calculated from the measured oxygen gradients as described in Kühl et al. (1996). The molecular diffusion coefficient of oxygen, $D_{0}$, corrected for temperature and salinity in accordance with the Unisense gas tables (Li \& Gregory 1974, Garcia \& Gordon 1992), was used to calculate the $\mathrm{O}_{2}$ fluxes in the diffusive boundary layer, whereas the effective diffusion coefficient, $D_{\mathrm{e}}$, calculated as $D_{\mathrm{e}}=D_{0} \Phi$, where $\Phi$ is sediment porosity (Kühl et al. 1996), was used for flux calculations in the sediment. The measured rates of $P_{\text {net }}$ were plotted against the incident light intensities, $I$, and fitted with the function $P_{\text {net }}=P_{\text {gross, sat }}\{1-$ $\left.\exp \left[-\ln (2) \times I / I_{1 / 2}\right]\right\}+R_{\text {phot }}$ (Webb et al. 1974) where $R_{\text {phot }}$ was the rate derived from microsensor measurements. During the fit, the value of the parameter $R_{\text {phot }}$ was forced to equal the measured rate $R_{\text {phot }}$. Assuming that the rates of respiration in the dark and in the light were equal, the parameters $P_{\text {gross,sat }}$ and $I_{1 / 2}$ obtained from the fit represent the areal rate of gross photosynthesis at light saturation and the halfsaturation light intensity, respectively. This fitting was done separately for $P$ - $I$ curves measured in each core, and the fitted values were averaged.

\section{Sedimentary oxygen consumption rates}

Potential sedimentary oxygen consumption rates (OCR) were measured as described in Polerecky et al. (2005) and Volkenborn et al. (2010). Freshly collected square sediment cores (width and breadth $70 \mathrm{~mm}$, length $200 \mathrm{~mm}$ ) equipped with a planar optode (Precht et al. 2004) were set up in a climate room, and the measurements were carried out at in situ temperature and in the dark. Oxygenated water was carefully injected next to the optode into the anoxic sediment regions at depths from 3.0 to $8.5 \mathrm{~cm}$ below sediment surface, and depletion in porewater $\mathrm{O}_{2}$ concentration was monitored at $30 \mathrm{~s}$ intervals. This was done simultaneously in 2 to 3 spots in each core. In 3 of the 4 cores measured, this was repeated twice, resulting overall in 3 to 6 measurements per core. The average size of the measured spots (as seen by the optode) was $0.33 \pm 0.14 \mathrm{~cm}^{2}$, with one area exceptionally large $\left(0.68 \mathrm{~cm}^{2}\right)$ and one exceptionally small $\left(0.07 \mathrm{~cm}^{2}\right)$. The values of OCR, expressed per volume of sediment, were calculated as rates of the porewater $\mathrm{O}_{2}$ depletion multiplied by sediment porosity (Polerecky et al. 2005). These measurements were made only for Svalbard sediments because of the evidence of deeper subsurface sediment oxygenation (see 'Results'), and not for the Helgoland sediments.

\section{Statistical analyses}

Statistical analyses in this study were performed using JMP 9.0 (SAS Institute, USA) with the signifi- 
cance level $\alpha$ set to 0.05 . Analysis of variance (1-way ANOVA) was performed to test whether the 2 study sites differed significantly with respect to sediment characteristics, pigment biomass, measured and calculated photosynthesis and respiration rates. Furthermore, we tested if volumetric oxygen consumption rates in the sub-surface sediments of the Svalbard site were significantly correlated with depth and if there were significant correlations between the in situ oxygen inventories (in and below the euphotic sediment zone) and the respective in situ light intensities in the sediments of both study sites.

\section{RESULTS}

\section{General settings}

The Svalbard and Helgoland sites are generally characterized as cold and temperate, with annual average water temperatures during the studied years of $2.4^{\circ} \mathrm{C}$ and $10.1^{\circ} \mathrm{C}$, respectively. During the in situ study period (June 2010 for Svalbard and August 2009 for Helgoland), average water temperatures in Svalbard and Helgoland were $4.8^{\circ} \mathrm{C}$ and $18.3^{\circ} \mathrm{C}$, respectively. Over a $24 \mathrm{~h}$ day period, light was present continuously in Svalbard, whereas there were $9 \mathrm{~h}$ of darkness in Helgoland (Table 2).

\section{Sediment characteristics}

Sediments at the sites were similar and generally characterized as well sorted, fine, porous, permeable sands (Table 2). Permeability did not significantly differ with depth down to $10 \mathrm{~cm}$ between the 2 sites (Table S1 in the Supplement at www.int-res.com/ articles/suppl/m504p027_supp.pdf). Porosity decreased with depth in Svalbard and was significantly higher than in the Helgoland sediment (Table S1).

Table 2. Characteristics of the sites in Svalbard and Helgoland. Shown are mean \pm SD values for N replicate measurements. TC: total carbon, TN: total nitrogen, TS: total sulfur, TIC: total inorganic carbon, TOC: total organic carbon, LOD: limit of detection, wt: weight, dw: dry weight. The carbon, nitrogen, sulfur and pigment data are normalized to sediment dry weight. Unless otherwise stated, all data were collected during the study periods 22 Jun-12 Jul 2010 for Svalbard and Aug 2009 for Helgoland

\begin{tabular}{|c|c|c|c|}
\hline Characteristic & Svalbard & Helgoland & $\mathrm{N}$ \\
\hline \multicolumn{4}{|l|}{ Environment } \\
\hline Sampling depth (m) & $5 \pm 0.2$ & $4.5 \pm 0.2$ & \\
\hline \multicolumn{4}{|l|}{ Water temperature $\left({ }^{\circ} \mathrm{C}\right)$} \\
\hline Annual & $2.4 \pm 2.1$ [Jun 2011-Jun 2012] & $10.1 \pm 5.7\left[\right.$ Jun 2009-Jun 2010] ${ }^{\mathrm{a}}$ & 26375,242 \\
\hline During study period & $4.8 \pm 1.6$ & $18.3 \pm 0.3^{\mathrm{a}}$ & 28080,20 \\
\hline Salinity & $31 \pm 2$ & 34 & \\
\hline Light:dark duration (h) & $24: 0$ & $15: 9$ & \\
\hline In situ PAR ( $\mu \mathrm{mol}$ photons $\left.\mathrm{m}^{-2} \mathrm{~s}^{-1}\right)$ & [22-23 (23-24) Jun 2010] & [11-12 Aug 2009] & \\
\hline Min & $4(12)$ & 0 & 2,2 \\
\hline Max & $230(73)$ & 339 & 2,2 \\
\hline Average $\pm \mathrm{SD}^{\mathrm{b}}$ & $49 \pm 46(33 \pm 21)$ & $62 \pm 78$ & 2,2 \\
\hline \multicolumn{4}{|l|}{ Sediment } \\
\hline Median grain size $(\mu \mathrm{m})$ & $147 \pm 3$ & $224 \pm 12$ & 6,3 \\
\hline Sorting & $0.50 \pm 0.01$ & $0.49 \pm 0.06$ & 6,3 \\
\hline Skewness & $0.061 \pm 0.004$ & $-0.09 \pm 0.02$ & 6,3 \\
\hline Porosity (vol\%), 0-10 cm & $0.44 \pm 0.02$ & $0.41 \pm 0.02$ & 5,2 \\
\hline Permeability $k\left[10^{-11} \mathrm{~m}^{-2}\right]$ & $0.95 \pm 0.17$ & $1.37 \pm 0.06$ & 2,2 \\
\hline $\mathrm{TC}(\% \mathrm{wt})$ & $2.56 \pm 0.18$ & $1.12 \pm 0.30$ & 6,5 \\
\hline TN (\%wt) & $0.019 \pm 0.005$ & $0.012 \pm 0.003$ & 6,5 \\
\hline TS (\%wt) & $0.033 \pm 0.008$ & $<\operatorname{LOD}(0.001)$ & 6,5 \\
\hline TIC (\%wt) & $0.10 \pm 0.02$ & $0.06 \pm 0.02$ & 6,5 \\
\hline TOC $[=\mathrm{TC}-\mathrm{TIC}],(\% \mathrm{wt})$ & $2.46 \pm 0.20$ & $1.06 \pm 0.32$ & 6,5 \\
\hline $\mathrm{C}: \mathrm{N}$ & $137 \pm 50$ & $95 \pm 31$ & 6,5 \\
\hline \multicolumn{4}{|l|}{ MPB biomass } \\
\hline Chl a $\left(\mu g g^{-1} \mathrm{dw}\right)$ & $13.9 \pm 5.6$ & $12.9 \pm 6.0$ & 5,6 \\
\hline Fucoxanthin $\left(\mu g g^{-1} \mathrm{dw}\right)$ & $7.6 \pm 2.2$ & $8.7 \pm 3.5$ & 5,6 \\
\hline
\end{tabular}



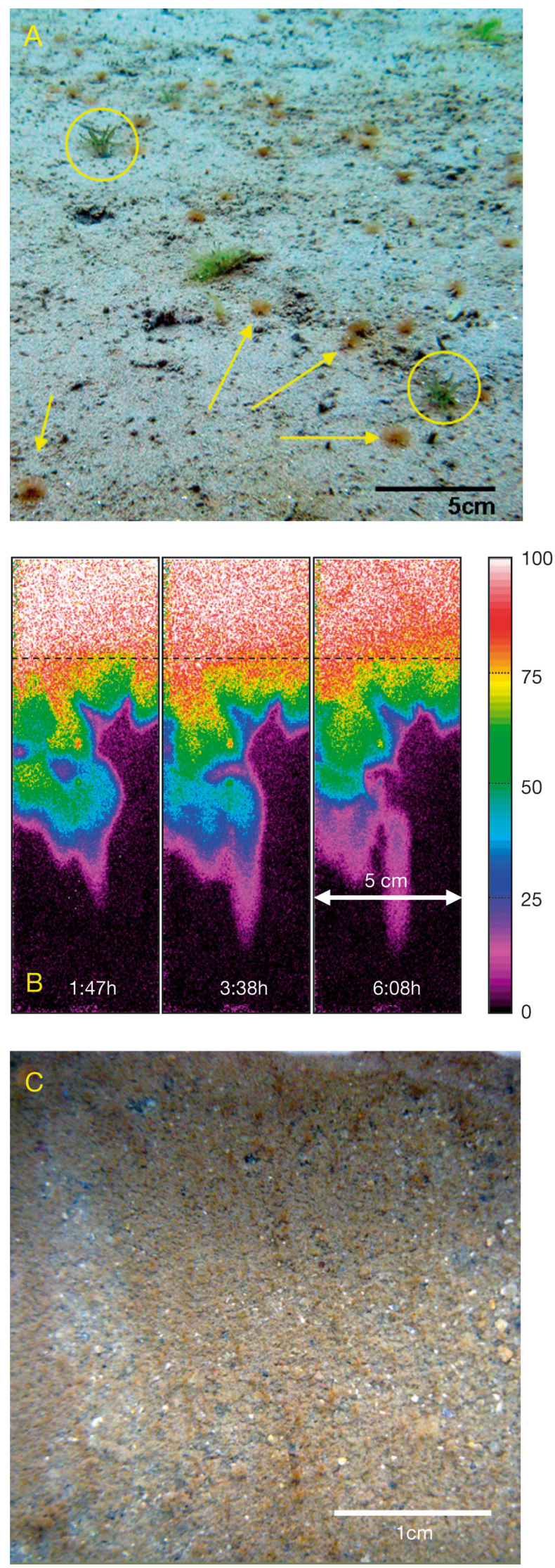

The most striking difference was a large abundance of macrofauna in the Svalbard sediments (mainly visible as polychaetes, crustaceans and sedimentary anemones), which were largely absent in Helgoland sediments (Fig. 2).

Total carbon and nitrogen contents were about 2 -fold higher in Svalbard than in Helgoland. Nitrogen contents were very low. Total organic carbon content was high at both sites, representing about $95 \%$ of the total carbon (Table 2). Bulk sediment C:N ratios ranged from 76 to 198 in Svalbard and from 63 to 145 in Helgoland, and were not significantly different between the sites (Table S1).

Porewater nutrient concentrations in the upper $12 \mathrm{~cm}$ in Svalbard sediments were generally low (see Fig. S1 in the Supplement). Silicate and nitrate concentrations were mostly $\leq 10 \mu \mathrm{M}$, whereas ammonium and phosphate usually ranged between 1 and $5 \mu \mathrm{M}$. Nitrite concentrations were low, varying between 0.1 and $0.2 \mu \mathrm{M}$. Especially in the upper 5 to $6 \mathrm{~cm}$ of the sediment, nitrogen compounds displayed notably low concentrations. Below these depths, only a single profile showed an increase, and overall no general trends with depth were detected. With the exception of silicate, nutrient concentrations in the overlaying water were $\sim 10$ fold lower than in the top centimeter of the sediment. For silicate the difference was $\sim 4$-fold. Thus, porewater nutrients could not be considered as limiting for microphytobenthos. Due to sample loss during transport, porewater nutrient profiles are not available for the Helgoland site.

\section{MPB community}

MPB biomass was highly variable within both sites, and there was no significant difference between the Svalbard and Helgoland site with respect to chl $a$ and

Fig. 2. (A) Photo of the sublitoral Arctic sediment from Brandal (Svalbard, $5 \mathrm{~m}$ depth, June 2010), showing the dense infaunal population. Arrows indicate the visible, extended, feather-like tentacle crowns of sedimentary polychaetes; circles highlight tentacles of sedimentary anemones. (B) Examples of oxygen distributions in the highly bioirrigated Svalbard sediment at specific times during a $24 \mathrm{~h}$ measurement. Dashed lines indicate the approximate location of the sediment surface; the color bar gives oxygen concentrations in percentage of air saturation. (C) Close-up photo of the sediment surface in a sediment core from Düne Süd (Helgoland, $4.5 \mathrm{~m}$ depth, August 2009) showing the relative lack of infaunal organisms compared to Svalbard. Photographs by D. S. Sevilgen 
fucoxanthin concentrations in the top $3 \mathrm{~mm}$ of the sediment (Table $\mathrm{S} 1$ in the Supplement). With respect to the MPB community composition, both sites were dominated by diatoms. Overall, 40 diatom species were identified, of which 18 were exclusively found in Svalbard, 11 exclusively in Helgoland, and 11 at both sites (see Table S2 \& Fig. S2 in the Supplement). All species belonged to the classes Bacillaryophyceae (39 species) and Coscinodiscophyceae (1 species). They were distributed amongst 19 genera, of which 11 are known to have species commonly found in polar regions. Three of these 11 genera were $\mathrm{Am}$ phora, Diploneis and Navicula, which cover $50 \%$ of all identified species in the studied sediments. Frequently found species exclusive to the Svalbard sediments were Plagiotropos lepidoptera, Donkina carinata, Planothidium delicatulum, Amphora sulcata, Pleurosigma normanii and Navicula directa. These species have been reported from polar regions previously but are also common in marine and brackish waters of the North Sea, the western Baltic and the NW Atlantic. Frequently observed species exclusive to the Helgoland sediments included Navicula cancellata and Petroneis humerosa, which are widespread in temperate marine and brackish waters, in coastal areas and on sandy shores but also in polar regions. Likewise, the species frequently found at both sites, Diploneis smithii, Petroneis marina and Amphora marina, are described as ubiquitous and have also been previously identified in polar habitats.

\section{In situ light and oxygen measurements}

In Svalbard, ambient light was present $24 \mathrm{~h}$ per day (June 2010). Light intensities generally followed a day:night cycle, with higher intensities during the day hours and lower intensities during the night, but sometimes weather conditions (cloud cover) caused intensities during the day to be lower than during the night (Fig. 3C). In situ oxygen microprofiles showed a small but detectable peak close to the sediment surface (Fig. 3A), indicative of photosynthetic activity by MPB organisms in the euphotic zone of the sediment. However, the most striking features of the profiles were elevated oxygen concentrations several centimeters below the sediment surface (Fig. 3A), demonstrating intensive bioirrigation of the sediment due to the ventilation activity of the infauna present. The average thickness of the oxygenated sediment layer was $2.25 \mathrm{~cm}$ over $24 \mathrm{~h}$. However, the complete set of measured profiles (data not shown) suggested that the bioventilationinduced oxygen penetration likely reached down to $6 \mathrm{~cm} . \mathrm{O}_{2}$ inventory in the euphotic zone of the sediment, obtained by depth-integration of the in situ $\mathrm{O}_{2}$ profiles over the top $2.5 \mathrm{~mm}$, varied from 0.1 to $0.3 \mathrm{mmol} \mathrm{O}_{2} \mathrm{~m}^{-2}$, whereas the $\mathrm{O}_{2}$ inventory below the euphotic zone was larger, by up to 10 -fold (Fig. 3C). The latter inventory values were likely underestimated, since the $\mathrm{O}_{2}$ concentrations were measured away from infaunal burrows (i.e. where they are known to be lower) and they often did not reach zero at the deepest points of the profiles. Unexpectedly, the $\mathrm{O}_{2}$ inventories in the sediment euphotic zone were significantly negatively correlated with light $(\mathrm{R}=-0.43, \mathrm{p}<0.001 ;$ Fig. $3 \mathrm{E})$. When integrated over a $24 \mathrm{~h}$ period, the $\mathrm{O}_{2}$ inventories below the euphotic zone constituted between $77 \%$ (first measuring day) and $92 \%$ (second measuring day) of the total sedimentary $\mathrm{O}_{2}$ inventory, indicating a highly significant impact of the infauna on the sediment biogeochemistry at this site.

In Helgoland, in situ light intensities followed a 15:9 h day:night cycle (Fig. 3D). In the light, oxygen showed a clear peak slightly below the sediment surface and penetrated down to $5 \mathrm{~mm}$ (Fig. 3B), indicative of photosynthetic activity by MPB organisms in the sediment euphotic zone and respiration below. In contrast, oxygen concentrations in the dark steeply declined with depth due to respiration, penetrating at most $2 \mathrm{~mm}$. During the day, the $\mathrm{O}_{2}$ inventory in the euphotic zone of the sediment were between 0.2 and $0.6 \mathrm{mmol} \mathrm{O}_{2} \mathrm{~m}^{-2}$ and about 2- to 10-fold higher than during the night. As expected, the $\mathrm{O}_{2}$ inventory in and below the sediment euphotic zone were significantly positively correlated with ambient light $(\mathrm{p}<$ 0.0001; Fig. 3F). When integrated over a $24 \mathrm{~h}$ period, the $\mathrm{O}_{2}$ inventory in the euphotic zone constituted about $92 \%$ of the total sedimentary $\mathrm{O}_{2}$ levels, suggesting the dominant role of light in the sedimentary $\mathrm{O}_{2}$ dynamics at this site.

\section{Laboratory rate measurements of photosynthesis and respiration}

Because the oxygen profiles measured in situ were not in steady state and (due to the highly significant animal activity in Svalbard) not diffusive, the rates of photosynthesis and respiration in the sediments were determined by laboratory microsensor measurements in treated cores. The net photosynthesis rates increased in relation with incident intensity of PAR and reached saturation at high 


\section{Svalbard}

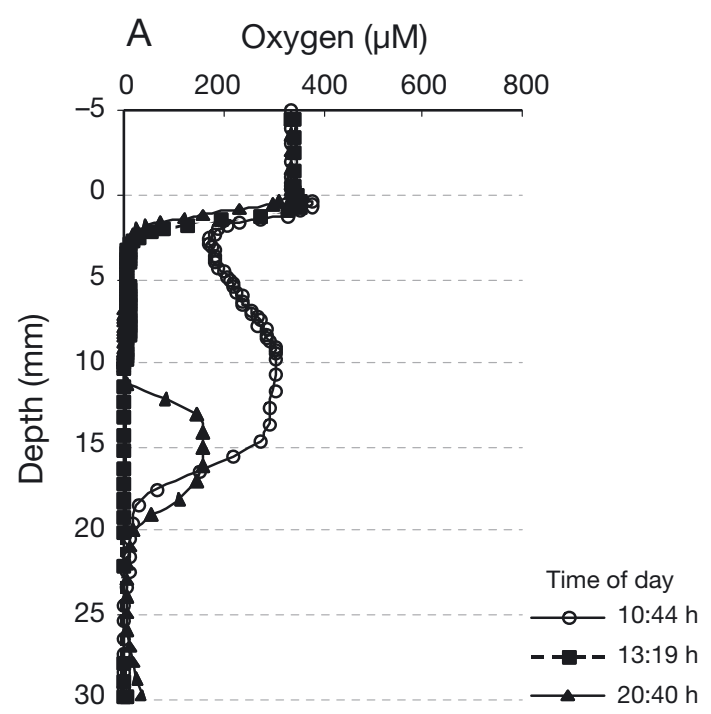

C

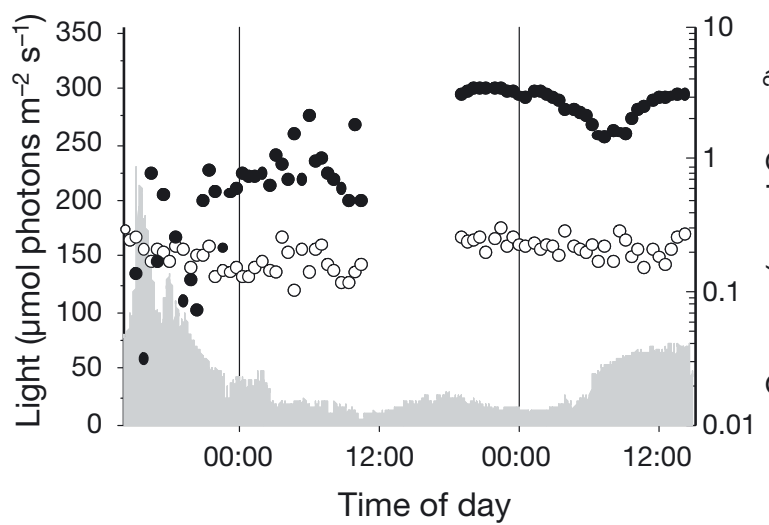

E

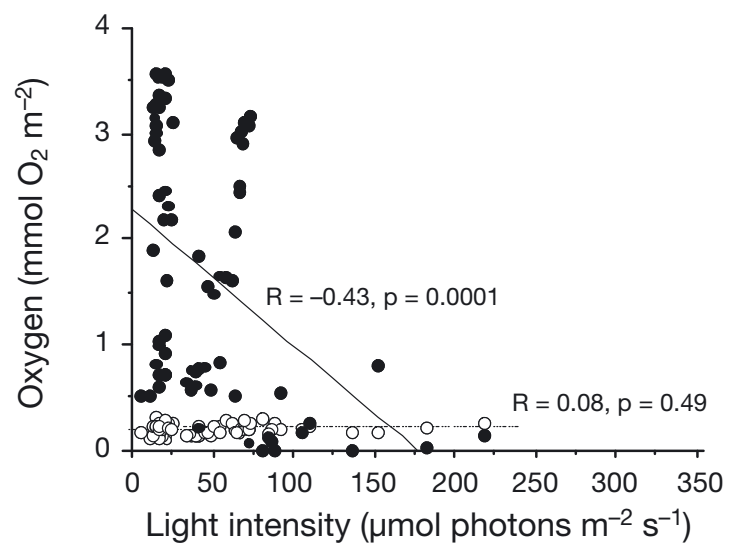

Helgoland

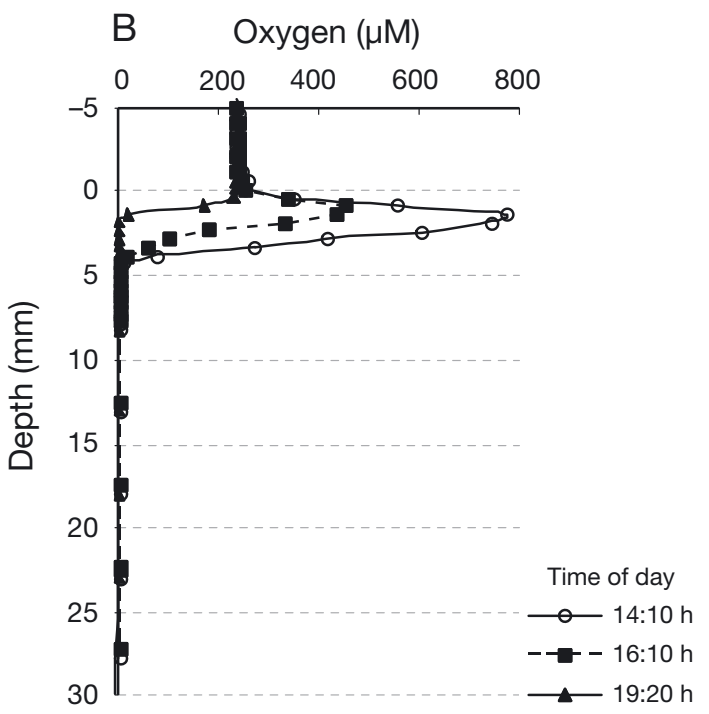

D

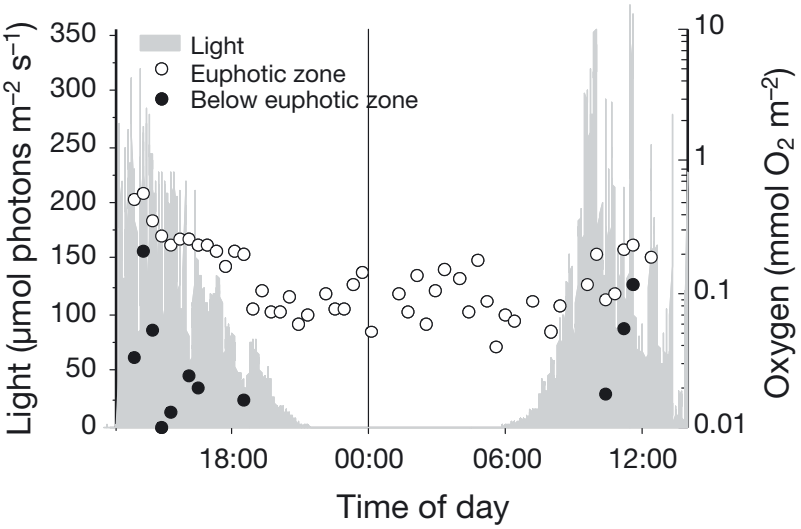

$\mathrm{F}$

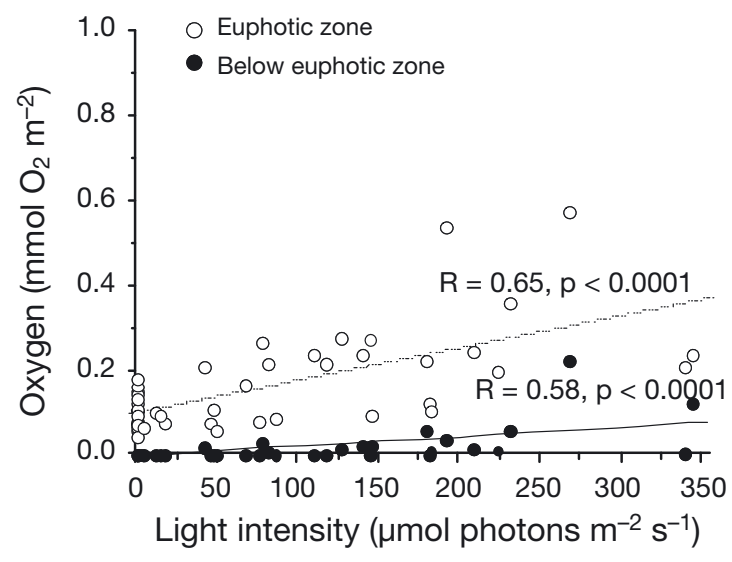

Fig. 3. (A,B) Selected in situ oxygen profiles in the Svalbard and Helgoland sediments, measured at the time of day (Svalbard: 23 Jun 2010, Helgoland: 11 Aug 2009) indicated in the key. Zero depth corresponds to the sediment-water interface. (C,D) In situ downwelling PAR intensity, overlaid with the oxygen concentrations in and below the sediment euphotic zone, as a function of time of day (Svalbard: 22-24 Jun 2010, Helgoland: 11-12 Aug 2009). Vertical solid lines indicate midnight. (E,F) Correlations between the oxygen concentrations and downwelling PAR intensities, derived from the time-series measurements shown in $(\mathrm{C}, \mathrm{D})$ 


\section{Svalbard}

A

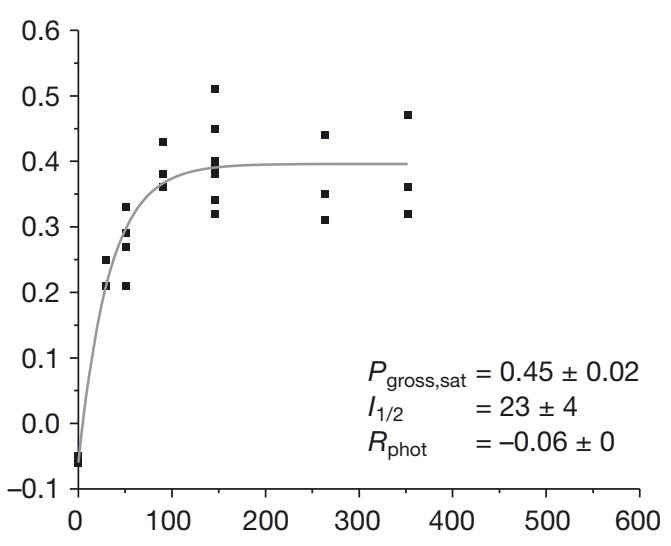

C

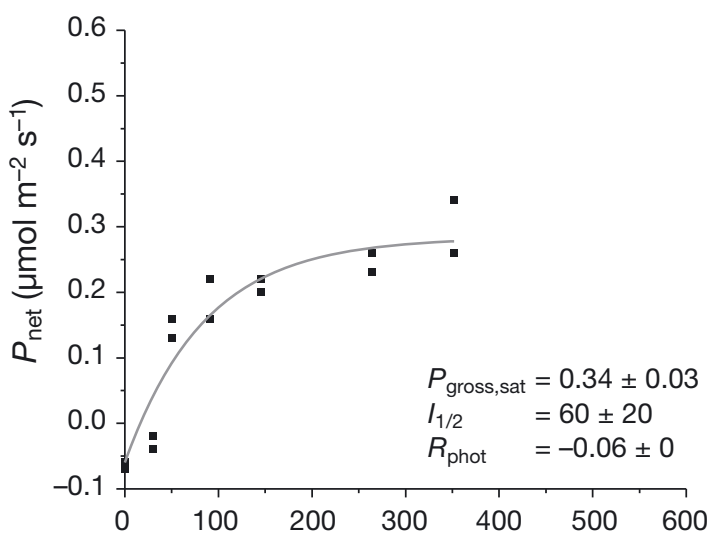

E

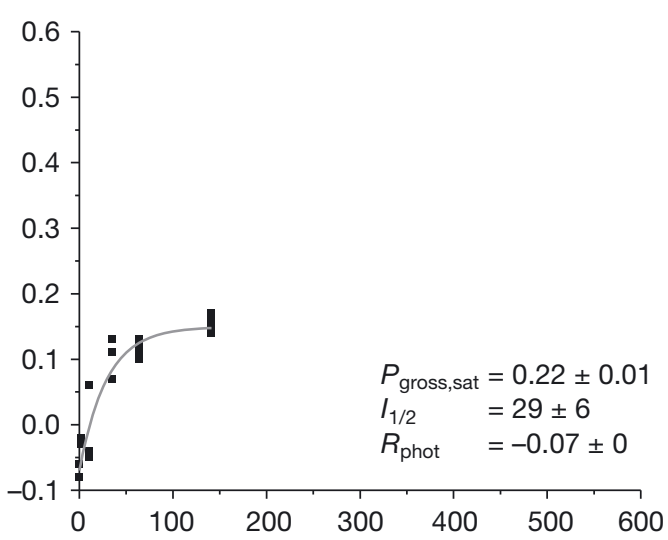

Helgoland

B

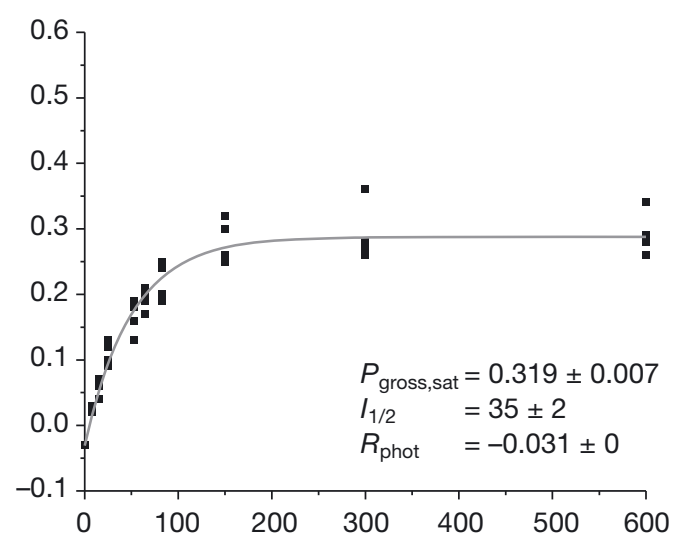

D

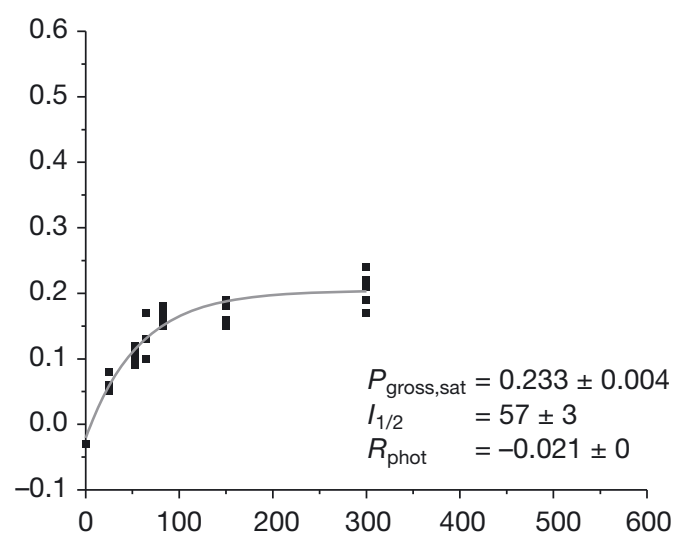

$\mathrm{F}$

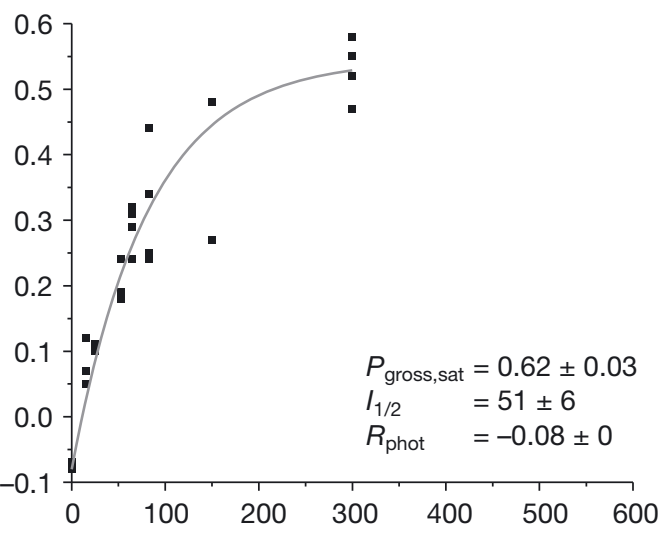

I ( $\mu \mathrm{mol}$ photons $\mathrm{m}^{-2} \mathrm{~s}^{-1}$ )

Fig. 4. Net photosynthesis $\left(P_{\text {net }}\right)$ rates as a function of downwelling irradiance ( $P-I$ curves), obtained from laboratory microsensor measurements in replicate sediment cores from Svalbard (A,C,E; June 2010) and Helgoland (B,D,F; August 2009). Symbols in each graph show experimental values obtained in random locations within one core; lines show the least-square fit by the model $P_{\text {net }}=P_{\text {gross,sat }}\left\{1-\exp \left[-\ln (2) \times I / I_{1 / 2}\right]\right\}+R_{\text {phot, }}$ with the values (means $\pm \mathrm{SE}$ ) of the corresponding fitting parameters given in the graph. $P_{\text {gross,sat }}=$ areal rate of gross photosynthesis at light saturation, $I_{1 / 2}=$ half-saturation light intensity, 
PAR intensities (Fig. 4). High variability between the measurements at each light intensity was most likely due to pronounced heterogeneity in the surface chl a concentration within the samples. Fitting of the $P$-I curves revealed that photosynthetic parameters (net and gross photosynthesis and the rates of respiration in the sediment euphotic zone) were not significantly different between the 2 sites (Table 3, Table S1 in the Supplement). The average half-saturation PAR intensities, $I_{1 / 2}$ (which characterize the adaptation of the community to light), and the average compensation PAR intensities, $I_{\mathrm{c}}$ (the intensities at which the community photosynthesis equals respiration), were comparatively low and similar for both sites (Table 3). Thus, the MPB at both sites was low-light adapted and showed similar photosynthetic performance.

Volumetric rates of oxygen consumption in subsurface sediments from Svalbard were highly variable within and between the sediment cores, and ranged from $\sim 8$ to $44 \mu \mathrm{mol}$ $\mathrm{O}_{2} \mathrm{~m}^{-3} \mathrm{~s}^{-1}$ (Table 3). No significant trends $(p=0.48)$ with depth in the top $8 \mathrm{~cm}$ of sediment were observed. The areal respiration rates, obtained by integration of the volumetric rates over the average $\mathrm{O}_{2}$ penetration depth determined in situ $(2.25 \mathrm{~cm})$, were about 6-fold higher than the areal respiration rates in the sediment euphotic zone and similar to the areal gross photosynthesis rates at light saturation (Table 3). Because oxygen is most likely present also below $3 \mathrm{~cm}$ depth, areal respiration rates below the euphotic zone are probably underestimated.
Table 3. Photosynthesis $(P)$ and respiration $(R)$ rates, and irradiance $(I)$, derived from laboratory measurements by oxygen microsensors and planar optodes. $P_{\text {net }}$ and $P_{\text {gross }}$ : net and gross photosynthesis, $R_{\text {phot }}$ : respiration in the euphotic zone, $I_{1 / 2}$ : half saturation downwelling PAR irradiance, $I_{\mathrm{c}}$ : compensation irradiance, $R_{\text {below_phot }}$ respiration below the euphotic zone. Shown are averages \pm SD (minimum, maximum) values of $\mathrm{N}$ replicate measurements. nd: not determined

\begin{tabular}{|c|c|c|c|c|}
\hline Parameter & Unit & Svalbard & Helgoland & $\mathrm{N}$ \\
\hline \multicolumn{5}{|c|}{ Microprofiles } \\
\hline$P_{\text {net }}$ & $\left(\mu \mathrm{mol} \mathrm{O} \mathrm{O}^{-2} \mathrm{~s}^{-1}\right)$ & $\begin{array}{l}0.28 \pm 0.12 \\
(0.15,0.39)\end{array}$ & $\begin{array}{l}0.34 \pm 0.17 \\
(0.20,0.54)\end{array}$ & 3,3 \\
\hline$R_{\text {phot }}$ & $\left(\mu \mathrm{mol} \mathrm{O} \mathrm{O}^{-2} \mathrm{~s}^{-1}\right)$ & $\begin{array}{l}-0.062 \pm 0.007 \\
(-0.055,-0.070)\end{array}$ & $\begin{array}{l}-0.048 \pm 0.032 \\
(-0.029,-0.085)\end{array}$ & 3,3 \\
\hline$P_{\text {gross }}$ & $\left(\mu \mathrm{mol} \mathrm{O} \mathrm{O}^{-2} \mathrm{~s}^{-1}\right)$ & $\begin{array}{l}0.34 \pm 0.11 \\
(0.22,0.45)\end{array}$ & $\begin{array}{l}0.39 \pm 0.21 \\
(0.23,0.62)\end{array}$ & 3,3 \\
\hline$I_{1 / 2}$ & $\left(\mu \mathrm{mol}\right.$ photons $\left.\mathrm{m}^{-2} \mathrm{~s}^{-1}\right)$ & $\begin{array}{l}34 \pm 22 \\
(23,60)\end{array}$ & $\begin{array}{l}43 \pm 11 \\
(35,55)\end{array}$ & 3,3 \\
\hline$I_{\mathrm{C}}$ & $\left(\mu \mathrm{mol}\right.$ photons $\left.\mathrm{m}^{-2} \mathrm{~s}^{-1}\right)$ & $\begin{array}{l}7 \pm 2 \\
(5,8)\end{array}$ & $\begin{array}{l}14 \pm 9 \\
(6,23)\end{array}$ & 3,3 \\
\hline \multicolumn{5}{|c|}{ Planar optodes (= $\left.R_{\text {below_phot }}\right)$} \\
\hline $\begin{array}{l}R_{\text {below_phot }} \\
\text { volumetric }\end{array}$ & ic $\left(\mu \mathrm{mol} \mathrm{O} \mathrm{O}^{-3} \mathrm{~s}^{-1}\right)$ & $\begin{array}{l}-16.4 \pm 15.8 \\
(-8.3,-44.3)\end{array}$ & nd & 5 \\
\hline $\begin{array}{l}R_{\text {below_phot' }} \\
\text { areal }^{\mathrm{a}}\end{array}$ & $\left(\mu \mathrm{mol} \mathrm{O} \mathrm{O}_{2} \mathrm{~m}^{-2} \mathrm{~s}^{-1}\right)$ & $\begin{array}{l}-0.37 \pm 0.36 \\
(-0.19,-1)\end{array}$ & nd & 3 \\
\hline \multicolumn{5}{|c|}{$\begin{array}{l}{ }^{a} \text { Values calculated for the average depth of oxygen penetration of } \\
2.25 \mathrm{~cm} \text {, as derived from in situ oxygen profiles during a } 24 \mathrm{~h} \text { interval } \\
\text { ( } \mathrm{N}=43 \text { profiles) }\end{array}$} \\
\hline
\end{tabular}

Table 4. Estimated in situ daily oxygen budgets for the 2 sites. Shown are averages $\pm \mathrm{SD}$ (minimum, maximum) values of $\mathrm{N}$ replicate measurements. The Svalbard budgets were estimated using the average in situ oxygen penetration depth of $2.25 \mathrm{~cm}$ (section A) and values ranging from 2 to $6 \mathrm{~cm}$ (section B). Daily $(24 \mathrm{~h})$ light doses were Svalbard: $3.5 \pm 1.0 \mathrm{~mol}$ photons $\mathrm{m}^{-2} \mathrm{~d}^{-1}(\mathrm{n}=2)$ and Helgoland: $5.3 \mathrm{~mol}$ photons $\mathrm{m}^{-2} \mathrm{~d}^{-1}(\mathrm{n}=1)$. nd: not determined

\begin{tabular}{|c|c|c|c|}
\hline \multicolumn{3}{|c|}{ (A) Oxygen budgets $\left(\mathrm{mmol} \mathrm{O}_{2} \mathrm{~m}^{-2} \mathrm{~d}^{-1}\right.$ ) } & $\mathrm{N}$ \\
\hline$P_{\text {gross }}$ & $14.8 \pm 7.0(9.9,22.9)$ & $13.4 \pm 5.7(8.5,19.7)$ & 6,3 \\
\hline$R_{\text {phot }}$ & $-5.4 \pm 0.6(-4.8,-6.1)$ & $-4.2 \pm 2.7(-2.5,-7.3)$ & 3,3 \\
\hline$R_{\text {below_phot }}$ & $-31.8 \pm 30.8(-16.2,-86.2)$ & nd & $3,-$ \\
\hline$P_{\text {net }}$ & $-22.4 \pm 31.6(-82.4,1.9)$ & $9.2 \pm 6.3(1.1,17.2)$ & 3,3 \\
\hline \multicolumn{4}{|c|}{$\begin{array}{l}\text { (B) Oxygen budgets for different depths of } \mathrm{O}_{2} \text { penetration } \\
\left(\mathrm{mmol} \mathrm{O} \mathrm{O}_{2} \mathrm{~m}^{-2} \mathrm{~d}^{-1}\right)\end{array}$} \\
\hline Depth $(\mathrm{cm})$ & Svalbard & Helgoland & $\mathrm{N}$ \\
\hline 2 & $-18 \pm 13(-73,4)$ & - & $3,-$ \\
\hline 4 & $-47 \pm 23(-149,-11)$ & - & $3,-$ \\
\hline 6 & $-75 \pm 34(-226,-25)$ & - & $3,-$ \\
\hline
\end{tabular}

\section{Estimates of daily oxygen budgets}

We estimated daily light and oxygen budgets in the Svalbard and Helgoland sediments using the values of gross photosynthesis, respiration and light adaptation intensity estimated from the laboratory measure- ments, and the values of available downwelling PAR intensity and depths of sediment oxygenation determined in situ. Because each parameter was estimated with some uncertainty, we combined the values so as to estimate the average, as well as the minimum and maximum values, for the daily oxygen budgets. 
For the Svalbard site, the PAR dose during the $24 \mathrm{~h}$ period was about $3.5 \mathrm{~mol}$ photons $\mathrm{m}^{-2} \mathrm{~d}^{-1}$. In comparison, the daily PAR dose at the Helgoland site was $\sim 50 \%$ higher, despite the extended period $(9 \mathrm{~h})$ of darkness (Table 4).

The estimated daily gross primary production was very similar for the Svalbard and Helgoland sites (Table 4). This is somewhat counterintuitive considering the roughly $50 \%$ higher daily PAR dose and about $15 \%$ higher rates of gross photosynthesis at light saturation in Helgoland (Table 3), and is related to the combined effects of the generally low-light adaptation of the 2 communities and to the continuous illumination at Svalbard, which led to an additional $9 \mathrm{~h}$ of primary productivity per day.

Considering only the sediment euphotic zone, about $40 \%$ of the daily primary production at Svalbard would be remineralized by aerobic respiration. However, due to the much deeper $\mathrm{O}_{2}$ penetration linked to sediment bioirrigation, the total estimated aerobic remineralization at this site exceeded production at least 2-fold, possibly up to about 5-fold, leading to a grossly negative daily $\mathrm{O}_{2}$ budget (Table 4). In contrast, remineralization by aerobic processes occurred only within the upper $5 \mathrm{~mm}$ of sediment at the Helgoland site, and the estimated net daily $\mathrm{O}_{2}$ budget was positive (about $9.17 \mathrm{mmol} \mathrm{O}_{2} \mathrm{~m}^{-2} \mathrm{~d}^{-1}$; Table 4).

\section{DISCUSSION}

\section{Microphytobenthic communities}

During the study period, the Svalbard and Helgoland MPB communities were dominated by diatoms. The large overlap (28\%) of identified species at both study sites and the dominance of cosmopolitans can be linked to the specific oceanographic setting of Kongsfjorden (Svalbard). A distinct Atlantic influence renders Kongsfjorden in the sub-Arctic rather than in the Arctic realm. Correspondingly, endemic species are rare, and North Atlantic species are present at all trophic levels of the fjord ecosystem (Hop et al. 2002, 2012). Some of the identified diatom species occur at both poles (e.g. Navicula directa and Actinocyclus actinochilus). However, morphological species analyses alone are sometimes not sufficient to decide on species identity (Mann 2010). Molecular biological tools are needed to check for the existence of cryptic species, which are likely to have developed due to the large geographical distance between the sites.

\section{Microphytobenthic photosynthesis}

Our data show that the concentrations of chlorophyll $a$ and fucoxanthin, the half-saturation and compensation light intensities, and the productivity at light saturation are similar for the studied MPB communities in Svalbard and Helgoland. Thus, despite the differences in ambient water temperatures, the 2 communities have similar photosynthetic potential and performance, and thus seem to be adapted to the prevailing local conditions.

With respect to light adaptation, MPB communities from both of our studied sites showed low-light adaptation, similar to results obtained previously for comparable communities. For example, our halfsaturation irradiance values, $I_{1 / 2}$, for the Svalbard community ( $34 \pm 22 \mu \mathrm{mol}$ photons $\mathrm{m}^{-2} \mathrm{~s}^{-1}$ ) include the average value of $19 \mu \mathrm{mol}$ photons $\mathrm{m}^{-2} \mathrm{~s}^{-1}$ obtained by Glud et al. (2009) for another arctic MPB community (from Greenland) during summer, while the slightly larger $I_{1 / 2}$ values determined for the Helgoland community $\left(43 \pm 11 \mu \mathrm{mol}\right.$ photons $\left.\mathrm{m}^{-2} \mathrm{~s}^{-1}\right)$ are comparable to those found previously for a temperate subtidal site in Brest, France $\left(40-58 \mu \mathrm{mol}\right.$ photons $\mathrm{m}^{-2}$ $\mathrm{s}^{-1}$; Ni Longphuirt et al. 2007). Compared to previously reported values in photosynthesis research (Kuhl et al. 1996, Denis et al. 2012), the compensation irradiances were also generally low (7 and $14 \mu \mathrm{mol}$ photons $\mathrm{m}^{-2} \mathrm{~s}^{-1}$ for Svalbard and Helgoland, respectively), although somewhat larger than those reported previously for an Arctic fjord in Greenland (4.7 $\mu \mathrm{mol}$ photons $\mathrm{m}^{-2} \mathrm{~s}^{-1}$; Glud et al. 2009) or for diverse coastal MPB communities (2.8 $\mu \mathrm{mol}$ photons $\mathrm{m}^{-2} \mathrm{~s}^{-1}$; Gattuso et al. 2006).

With respect to MPB photosynthesis, our data are also similar to those available in the literature for comparable communities (Table 5). For example, daily benthic primary production estimated for our Svalbard site (10-23 mmol $\left.\mathrm{O}_{2} \mathrm{~m}^{-2} \mathrm{~d}^{-1}\right)$ lies within the range determined for other sites in Kongsfjorden (2-48 mmol $\mathrm{O}_{2} \mathrm{~m}^{-2} \mathrm{~d}^{-1}$; Woelfel et al. 2010), although it is smaller than previous estimates for the same site (Brandal, 37 to $47 \mathrm{mmol} \mathrm{O}_{2} \mathrm{~m}^{-2} \mathrm{~d}^{-1}$; Woelfel et al. 2010). This discrepancy is likely due to differences in light conditions used to estimate the daily $\mathrm{O}_{2}$ budgets. While we used the naturally variable light intensities measured in situ to estimate daily oxygen budgets in this study, our calculations for budgets of the study of Woelfel et al. (2010) were based on a fixed light intensity they used $\left(100 \mu \mathrm{mol}\right.$ photons $\mathrm{m}^{-2}$ $\mathrm{s}^{-1}$ ) and thus on a higher daily light dose $(8.6 \mathrm{~mol}$ photons $\left.\mathrm{m}^{-2} \mathrm{~d}^{-1}\right)$ than that measured by us $(3.5 \mathrm{~mol}$ photons $\mathrm{m}^{-2} \mathrm{~d}^{-1}$, Table 4). It is known that when in 
Table 5. Comparison of daily oxygen budgets in sublitoral MPB communities from different Arctic and temperate sites

\begin{tabular}{|c|c|c|c|c|c|c|}
\hline Site & $\begin{array}{l}\text { Depth } \\
\text { (m) }\end{array}$ & $\begin{array}{c}\text { Gross } \\
\mathrm{O}_{2} \text { production } \\
\left(\mathrm{mmol} \mathrm{O}_{2} \mathrm{~m}^{-2} \mathrm{~d}^{-1}\right)\end{array}$ & $\begin{array}{c}\mathrm{O}_{2} \\
\text { consumption } \\
\left(\mathrm{mmol} \mathrm{O}_{2} \mathrm{~m}^{-2} \mathrm{~d}^{-1}\right)\end{array}$ & Method & Date & Source \\
\hline $\begin{array}{l}\text { All sites, Kongsfjorden } \\
\text { Brandal, Kongsfjorden }\end{array}$ & $\begin{array}{c}\leq 5 \text { to } 30 \\
5\end{array}$ & $\begin{array}{r}2 \text { to } 48^{\mathrm{a}} \\
\sim 38 \text { to } 47^{\mathrm{a}}\end{array}$ & $\begin{array}{c}-2 \text { to }-35^{b} \\
\sim-35^{b}\end{array}$ & $\begin{array}{l}\text { Planar } \mathrm{O}_{2} \text { optode } \\
\text { sensor spots }\end{array}$ & Summer 2007 & $\begin{array}{l}\text { Woelfel et al. } \\
\qquad(2010)\end{array}$ \\
\hline $\begin{array}{l}\text { Nivå Bay, Denmark } \\
\text { Adventfjord, } \\
\text { Svalbard/Arctic }\end{array}$ & $\begin{array}{l}0.4 \pm 0.3 \\
1.3 \pm 0.6\end{array}$ & $\begin{array}{c}28.8^{\mathrm{a}} \\
-\end{array}$ & $\begin{array}{c}-8 \text { to }-9^{\mathrm{c}} \\
\sim-9 \text { to }-17^{\mathrm{c}}\end{array}$ & $\mathrm{O}_{2}$ microsensors & $\begin{array}{l}\text { February } 2001 \\
\text { May } 2000\end{array}$ & $\begin{array}{c}\text { Hancke \& Glud } \\
\text { (2004) }\end{array}$ \\
\hline Brandal, Kongsfjorden & 5 & $\begin{array}{c}10 \text { to } 23 \\
10 \text { to } 23 \\
9 \text { to } 20\end{array}$ & $\begin{array}{l}-5 \text { to }-6^{\mathrm{c}} \\
-16 \text { to }-86^{\mathrm{b}} \\
-3 \text { to }-7^{\mathrm{c}}\end{array}$ & $\begin{array}{c}\mathrm{O}_{2} \text { microsensors } \\
\text { Planar } \mathrm{O}_{2} \text { optodes } \\
\mathrm{O}_{2} \text { microsensors }\end{array}$ & $\begin{array}{l}\text { Summer } \\
2010 / 2011\end{array}$ & Present study \\
\hline \multicolumn{7}{|c|}{$\begin{array}{l}{ }^{\text {a } V a l u e s ~ a r e ~ e s t i m a t e d ~ b a s e d ~ o n ~ t h e ~ d a t a ~ i n ~ t h e ~ r e s p e c t i v e ~ s t u d y . ~ D a i l y ~ g r o s s ~ p r o d u c t i o n ~ r a t e s ~ f r o m ~ o u r ~ s t u d y ~ a r e ~ c a l c u l a t e d ~} \\
\text { using } 24 \mathrm{~h} \text { in situ light intensities, whereas calculations for the other studies are extrapolated from production rates at } \\
\text { fixed experimental light intensities (see 'Discussion' for details) } \\
{ }^{\mathrm{b}} \text { Integrated sediment } \mathrm{O}_{2} \text { consumption (euphotic \& below euphotic zone) } \\
{ }^{\mathrm{c}} \mathrm{O}_{2} \text { consumption estimates within the sediment euphotic zone from } 0 \text { to } 3^{\circ} \mathrm{C}\end{array}$} \\
\hline
\end{tabular}

situ conditions are not taken into account, extrapolations can lead to overestimated budgets (Denis et al. 2012). Regarding the temperate site in Helgoland, our estimated daily $\mathrm{O}_{2}$ budget ( 9 to $20 \mathrm{mmol} \mathrm{O}_{2} \mathrm{~m}^{-2}$ $\mathrm{d}^{-1}$ ) was similar to but somewhat lower than that which we determined for the study by Hancke \& Glud (2004) for a comparable site in Nivå Bay, Denmark (28.8 mmol $\mathrm{m}_{2} \mathrm{~m}^{-2} \mathrm{~d}^{-1}$ ) (Table 5). The difference could be due to local conditions or again due to differences in light conditions applied when calculating the budget (i.e. constant incident light intensity of $140 \mu \mathrm{mol}$ photons $\mathrm{m}^{-2} \mathrm{~s}^{-1}$ resulting in a daily light dose of $12 \mathrm{~mol}$ photons $\mathrm{m}^{-2} \mathrm{~d}^{-1}$ vs. variable light intensity measured in situ with a daily light dose of $5.3 \mathrm{~mol}$ photons $\mathrm{m}^{-2} \mathrm{~d}^{-1}$ for the study of Hancke \& Glud [2004] and our study respectively).

\section{Benthic respiration}

Our respiration rates, integrated for the whole sediment community of Brandal, are in the same range as those determined previously for intact sediment cores of the same site, although our maximum estimate (-86 mmol $\mathrm{O}_{2} \mathrm{~m}^{-2} \mathrm{~d}^{-1}$ ) exceeds previously determined maximum rates by Woelfel et al. (2010) by a factor of about 2.5. These differences may be related to heterogeneity of the studied system. Our sediment dark respiration rates of the euphotic zone determined from microsensor measurements are slightly lower but well comparable with rates measured by Hancke \& Glud (2004) using the same method (Table 5) and show no differences between the arctic and temperate site.
While respiration in the sediment euphotic zone was similar at Svalbard and Helgoland, total respiration in the Svalbard sediment greatly exceeded respiration in the Helgoland sediments due to high infaunal activity. Laudien et al. (2007) reported high infaunal biomass in Brandal/Kongsfjorden (2260 infauna ind. $\mathrm{m}^{-2}$ at $5 \mathrm{~m}$ water depth), with macrozoobenthos composed of annelids (79\%), molluscs (11\%) and crustaceans $(8 \%)$, and the shallow $(5 \mathrm{~m})$ soft sediment fauna dominated by suspension-feeding or surface and sub-surface detritovorous polychaetes and deposit-feeding amphipods. It has been suggested that macrozoobenthos communities in the intertidal and shallow subtidal zones in the Arctic develop seasonally, and that community development (species richness, diversity and biomass) in the shallow subtidal zone is mainly affected by ice scouring (Bick \& Arlt 2005, Laudien et al. 2007). Therefore, the macrozoobenthos community found at the Arctic site in the present study will likely not persist throughout all seasons but may be present only during summer months. Owing to bioirrigation and oxygenation of deeper sediment layers by this fauna, biotic oxygen respiration and the abiotic oxidation of reduced inorganic compounds are stimulated. This stimulation results in elevated oxygen consumption, which in our study was roughly 10fold higher in Svalbard than in the Helgoland sediments. Macrozoobenthos (as present in the Svalbard sediments) was not observed in the Helgoland sediments, and our measurements indicated no bioirrigation at the Helgoland site. No infauna studies on shallow subtidal sandy sediments around Helgoland are available. 
To enable quantification of rates from the microsensor measurements, the measured profiles had to be diffusion controlled. For this, the infauna in the Svalbard sediments had to be eliminated or have its activity stopped. This was achieved by sieving the sediment or purging the overlaying water with $\mathrm{N}_{2}$, which may have affected our measurements. However, we expect that these effects were insignificant. Regarding the MPB, the sediment cores were illuminated to enable ongoing photosynthesis during $\mathrm{N}_{2}$ purging and the upper $5 \mathrm{~mm}$ of the sediments (in contrast to the rest of the core that was sieved) were left intact. Regarding the infauna, the exclusion or reduction of infauna activity was not selective and likely included meiofauna activity. Microsensorderived respiration rates for Svalbard may thus be underestimated, and accordingly the net photosynthesis rates may be overestimated.

\section{Drivers of high infauna abundance and respiration in Svalbard sediments}

Total organic carbon content and $\mathrm{C}: \mathrm{N}$ ratios were higher in the Svalbard than in the Helgoland sediments but not significantly different. The TOC content detected in Svalbard is similar to previous descriptions of marine surface sediments in the KongsfjordenKrossfjorden system (Kim et al. 2011). Organic matter in marine sediments can originate from benthic, pelagic and also sea-ice production, or from terrestrial input. The high $\mathrm{C}: \mathrm{N}$ ratios indicate terrestrial organic matter input (e.g. coal), representing refractory (i.e. not bio-available) carbon. Recently, Kim et al. (2011) analyzed single organic matter contributors to sediments of the Kongsfjorden-Krossfjorden system. They documented high coal-derived organic matter content in the marine surface sediments in close vicinity to Ny Alesund, which is a former coalmining site. Ancient organic matter is much less or not degradable compared to fresh organic matter. Thus, it can elevate carbon concentrations, supporting very high $\mathrm{C}: \mathrm{N}$ ratios, but will not be available as a food source for the infauna.

Spring blooms in Kongsfjorden produce a great amount of bioavailable organic matter (e.g. 27 to $35 \mathrm{~g}$ $\mathrm{C} \mathrm{m}^{-2}$ during the spring bloom from April $18^{\text {th }}$ to May $13^{\text {th }}$ 2002; Hodal et al. 2012), which can be either grazed in the water column or sink to the sea floor where it is grazed or buried. Hodal et al. (2012) showed that the spring bloom production in AprilMay was highest in shallow water depths (0-10 m), usually showing maxima at $5 \mathrm{~m}$. The high pelagic organic matter input represents an increased food supply. This, in turn, can support high abundance of infauna, which bioirrigate the sediment through ventilation of their burrows and thus increase the extent and depth of oxygen penetration into the sediment. As the interfacial oxygen uptake increased, sedimentary oxygen consumption rates increased. Additionally, sediment reworking, which is another effect of bioturbation by animals, returns reduced compounds from anoxic layers to the oxic part of the sediment, allowing these compounds to contribute to oxygen consumption through biotic and abiotic oxidation.

\section{CONCLUSION}

For the studied Arctic (Svalbard, Norway) and temperate (Helgoland, North Sea, Germany) sites, MPB communities and their photosynthetic potential showed no site specificity and were similar during the studied summer months. A dense infauna population was observed in the Svalbard sediments that may have been fueled by organic matter input from previous pelagic (spring) blooms. Oxygen budgets of the Svalbard sediments are therefore highly controlled by infauna activity and result in net heterotrophy, whereas the net positive oxygen budget in the Helgoland sediments is primarily governed by the photosynthetic oxygen production and thus controlled by light. Thus, we decline the first hypothesis that oxygen dynamics are controlled by MPB activity at both sites, and confirm the second hypothesis that both MPB communities show similar photosynthesis performance.

Acknowledgements. This study was supported by the POLMAR graduate school, the Alfred Wegener Institute, Helmholtz Centre for Polar and Marine Research (AWI); and the Max Planck Institute for Marine Microbiology (MPI). We are grateful for the support of the AWIPEV and Kings Bay staff in Ny Ålesund, and our colleagues at the Biologische Anstalt Helgoland. We thank Max Schwanitz, Sebastian Baumgarten, Philipp Fischer, Stephanie Wehkamp, Matthias Wehkamp, Elisa Bayraktarov and Antje Klawon for their diving support. We gratefully acknowledge all the technicians of the microsensor department for provision of the microsensors.

\section{LITERATURE CITED}

Bick A, Arlt G (2005) Intertidal and subtidal soft-bottom macro- and meiofauna of the Kongsfjord (Spitsbergen). Polar Biol 28:550-557

Cahoon LB (1999) The role of benthic microalgae in neritic 
ecosystems. Oceanogr Mar Biol Ann Rev 37:47-86

Cahoon LB (2006) Upscaling primary production estimates: regional and global scale estimates of microphytobenthos production. In: Kromkamp JC, de Brower JFC, Blanchard GF, Forster RM, Créach V (eds) Functioning of microphytobenthos in estuaries. Royal Netherlands Academy of Arts and Sciences, Amsterdam

> Denis L, Gevaert F, Spilmont N (2012) Microphytobenthic production estimated by in situ oxygen microprofiling: short-term dynamics and carbon budget implications. J Soils Sediments 12:1517-1529

Evrard V, Soetaert K, Heip CHR, Huettel M, Xenopoulos MA, Middelburg JJ (2010) Carbon and nitrogen flows through the benthic food web of a photic subtidal sandy sediment. Mar Ecol Prog Ser 416:1-16

Friedman GM, Sanders FE (1978) Principles of sedimentology. Wiley, New York, NY

> Garcia HE, Gordon LI (1992) Oxygen solubility in seawater-better fitting equations. Limnol Oceanogr 37: 1307-1312

Gattuso JP, Gentili B, Duarte CM, Kleypas JA, Middelburg JJ, Antoine D (2006) Light availability in the coastal ocean: impact on the distribution of benthic photosynthetic organisms and their contribution to primary production. Biogeosciences 3:489-513

Germain H (1981) Flore des diatomées d'eaux douces et saumâtres du Massif Armoricain et des contrées voisines d'Europe occidentale. Societé Nouvelle des Éditions Boubée, Paris

Glud RN, Kuhl M, Wenzhöfer F, Rysgaard S (2002) Benthic diatoms of a high Arctic fjord (Young Sound, NE Greenland): importance for ecosystem primary production. Mar Ecol Prog Ser 238:15-29

Glud RN, Woelfel J, Karsten U, Kuhl M, Rysgaard S (2009) Benthic microalgal production in the Arctic: applied methods and status of the current database. Bot Mar 52: 559-571

> Hancke K, Glud RN (2004) Temperature effects on respiration and photosynthesis in three diatom-dominated benthic communities. Aquat Microb Ecol 37:265-281

Hendey NI (1964) Bacillariophyceae (diatoms). In: Great Britain. Ministry of Agriculture, Fisheries and Food. Fishery investigations, Series 4. An introductory account of the smaller algae of British coastal waters. Part V. HMSO, London

> Hodal H, Falk-Petersen S, Hop H, Kristiansen S, Reigstad M (2012) Spring bloom dynamics in Kongsfjorden, Svalbard: nutrients, phytoplankton, protozoans and primary production. Polar Biol 35:191-203

Hop H, Pearson T, Hegseth EN, Kovacs KM and others (2002) The marine ecosystem of Kongsfjorden, Svalbard. Polar Res 21:167-208

> Hop H, Wiencke C, Vogele B, Kovaltchouk NA (2012) Species composition, zonation, and biomass of marine benthic macroalgae in Kongsfjorden, Svalbard. Bot Mar 55: $399-414$

Hustedt F (1958) Diatomeen aus der Antarktis und dem Südatlantik. In: Deutsche Antarktische Expedition 1938/ 39, Vol 2. Geogr.-Kartogr. Anstalt "Mundus", Hamburg, p 103-191

Hustedt F (1961-1966) Die Kieselalgen Deutschlands, Österreichs und der Schweiz unter Berücksichtigung der übrigen Länder Europas sowie der angrenzenden Meeresgebiete, Vol 7. Akademische Verlagsgesellschaft, Leipzig
Ito H, Kudoh S (1997) Characteristics of water in Kongsfjorden, Svalbard. Proc NIPR Symp Polar Meteorol Glaciol 11:211-234

> Jakobsson M (2002) Hypsometry and volume of the Arctic Ocean and its constituent seas. Geochem Geophys Geosyst 3(5):1-18, doi:10.1029/2001GC000302

> Kerouel R, Aminot A (1997) Fluorometric determination of ammonia in sea and estuarine waters by direct segmented flow analysis. Mar Chem 57:265-275

> Kim JH, Peterse F, Willmott V, Kristensen DK, Baas M, Schouten S, Damste JSS (2011) Large ancient organic matter contributions to Arctic marine sediments (Svalbard). Limnol Oceanogr 56:1463-1474

Klute A, Dirksen C (1986) Hydraulic conductivity and diffusivity: laboratory methods. In: Klute A (ed) Methods of soil analysis. Part 1. Physical and mineralogical methods. American Society of Agronomy and Soil Science Society of America, Madison, WI, p 687-734

Krammer K, Lange-Bertalot H (1986) Bacillariophyceae 1. Teil. Naviculaceae. Gustav Fischer Verlag, Stuttgart

Krammer K, Lange-Bertalot H (1988) Bacillariophyceae 2. Teil. Bacillariaceae, Epithemiaceae, Surirellaceae. Gustav Fischer Verlag, Stuttgart

Krammer K, Lange-Bertalot H (2000) Bacillariophyceae 3. Teil. Centrales, Fragilariaceae, Eunotiaceae. Spektrum Akademischer Verlag, Heidelberg

Kühl M, Glud RN, Ploug H, Ramsing NB (1996) Microenvironmental control of photosynthesis and photosynthesiscoupled respiration in an epilithic cyanobacterial biofilm. J Phycol 32:799-812

Kühl M, Glud RN, Borum J, Roberts R, Rysgaard S (2001) Photosynthetic performance of surface-associated algae below sea ice as measured with a pulse amplitudemodulated (PAM) fluorometer and $\mathrm{O}_{2}$ microsensors. Mar Ecol Prog Ser 223:1-14

> Laudien J, Herrmann M, Arntz WE (2007) Soft bottom species richness and diversity as a function of depth and iceberg scour in Arctic glacial Kongsfjorden (Svalbard). Polar Biol 30:1035-1046

> Laxon SW, Giles KA, Ridout AL, Wingham DJ and others (2013) CryoSat-2 estimates of Arctic sea ice thickness and volume. Geophys Res Lett 40:732-737

Li YH, Gregory S (1974) Diffusion of ions in sea water and in deep-sea sediments. Geochim Cosmochim Acta 38: 703-714

MacIntyre HL, Geider RJ, Miller DC (1996) Microphytobenthos: the ecological role of the "secret garden" of unvegetated, shallow-water marine habitats. I. Distribution, abundance and primary production. Estuaries 19:186-201

> Mann DG (2010) Discovering diatom species: Is a long history of disagreements about species-level taxonomy now at an end? Plant Ecol Evol 143:251-264

> Menard HW, Smith SM (1966) Hypsometry of ocean basin provinces. J Geophys Res 71:4305-4325

> Ni Longphuirt S, Clavier J, Grall J, Chauvaud L and others (2007) Primary production and spatial distribution of subtidal microphytobenthos in a temperate coastal system, the Bay of Brest, France. Estuar Coast Shelf Sci 74: 367-380

> Polerecky L, Franke U, Werner U, Grunwald B, de Beer D (2005) High spatial resolution measurement of oxygen consumption rates in permeable sediments. Limnol Oceanogr Methods 3:75-85

Precht E, Franke U, Polerecky L, Huettel M (2004) Oxygen dynamics in permeable sediments with wave-driven 
pore water exchange. Limnol Oceanogr 49:693-705

Reiss H, Wieking G, Kroencke I (2007) Microphytobenthos of the Dogger Bank: a comparison between shallow and deep areas using phytopigment composition of the sediment. Mar Biol 150:1061-1071

Revsbech NP (1989) An oxygen microsensor with a guard cathode. Limnol Oceanogr 34:474-478

Riaux-Gobin C, Llewellyn CA, Klein B (1987) Microphytobenthos from two subtidal sediments from North Brittany. II. Variations of pigment compositions and concentrations determined by HPLC and conventional techniques. Mar Ecol Prog Ser 40:275-283

Scholz B, Liebezeit G (2012) Microphytobenthic dynamics in a Wadden Sea intertidal flat-Part I: Seasonal and spatial variation of diatom communities in relation to macronutrient supply. Eur J Phycol 47:105-119

Scott FJ, Thomas DP (2005) Diatoms. In: Scott FJ, Marchant HJ (eds) Antarctic marine protists. Australian Biological Resources Study and Australian Antarctic Division, Canberra, p 13-201

Serreze MC, Holland MM, Stroeve J (2007) Perspectives on the Arctic's shrinking sea-ice cover. Science 315: 1533-1536

Sundbäck K, Enoksson V, Granéli W, Pettersson K (1991) Influence of sublittoral microphytobenthos on the oxygen and nutrient flux between sediment and water: a laboratory continuous-flow study. Mar Ecol Prog Ser 74: 263-279

Svendsen H, Beszczynska-Moller A, Hagen JO, Lefauconnier B and others (2002) The physical environment of Kongsfjorden-Krossfjorden, an Arctic fjord system in Svalbard. Polar Res 21:133-166

Underwood GJC, Kromkamp J (1999) Primary production by phytoplankton and microphytobenthos in estuaries. Adv Ecol Res 29:93-153

Volkenborn N, Polerecky L, Wethey DS, Woodin SA (2010) Oscillatory porewater bioadvection in marine sediments induced by hydraulic activities of Arenicola marina. Lim-

Editorial responsibility: Erik Kristensen,

Odense, Denmark nol Oceanogr 55:1231-1247

> Webb W, Newton M, Starr D (1974) Carbon dioxide exchange of Almus rubra: a mathematical model. Oecologia 17:281-291

> Weber M, Faerber P, Meyer V, Lott C, Eickert G, Fabricius KE, De Beer D (2007) In situ applications of a new diveroperated motorized microsensor profiler. Environ Sci Technol 41:6210-6215

> Wentworth CK (1922) A scale of grade and class terms for clastic sediments. J Geol 30:377-392

Wenzhöfer F, Glud RN (2004) Small-scale spatial and temporal variability in coastal benthic $\mathrm{O}_{2}$ dynamics: Effects of fauna activity. Limnol Oceanogr 49:1471-1481

Wieland A, Kühl M (2000) Short-term temperature effects on oxygen and sulfide cycling in a hypersaline cyanobacterial mat (Solar Lake, Egypt). Mar Ecol Prog Ser 196: 87-102

Wiltshire $\mathrm{KH}$, Malzahn AM, Wirtz K, Greve W and others (2008) Resilience of North Sea phytoplankton spring bloom dynamics: An analysis of long-term data at Helgoland Roads. Limnol Oceanogr 53:1294-1302

Witkowski A, Lange-Bertalot H, Metzeltin D (2000) Diatom flora of marine coasts. Iconographia diatomologica: annotated diatom micrographs, Vol 7. ARG Gantner Verlag, Vaduz, Liechtenstein

Woelfel J, Schumann R, Peine F, Flohr A and others (2010) Microphytobenthos of Arctic Kongsfjorden (Svalbard, Norway): biomass and potential primary production along the shore line. Polar Biol 33:1239-1253

> Wright SW, Jeffrey SW, Mantoura RFC, Llewellyn CA, Bjornland T, Repeta D, Welschmeyer N (1991) Improved HPLC method for the analysis of chlorophylls and carotenoids from marine phytoplankton. Mar Ecol Prog Ser 77:183-196

> Zhang JL, Lindsay R, Schweiger A, Rigor I (2012) Recent changes in the dynamic properties of declining Arctic sea ice: a model study. Geophys Res Lett 39:L20503, doi: 10.1029/2012GL053545

Submitted: March 28, 2013; Accepted: November 28, 2013 Proofs received from author(s): April 15, 2014 